\title{
Implications of deep drainage through saline clay for groundwater recharge and sustainable cropping in a semi-arid catchment, Australia
}

\author{
W. A. Timms ${ }^{1}$, R. R. Young ${ }^{2}$, and N. Huth ${ }^{3}$ \\ ${ }^{1}$ National Centre for Groundwater Research and Training, School of Mining Engineering, University of New South Wales, \\ Sydney, NSW, Australia \\ ${ }^{2}$ Tamworth Agricultural Institute, NSW Department of Primary Industry, NSW, Australia \\ ${ }^{3}$ Ecosystem Sciences, Agricultural Production Systems Research Unit, CSIRO, Toowoomba, Queensland, Australia
}

Correspondence to: W. A. Timms (w.timms@wrl.unsw.edu.au)

Received: 5 October 2011 - Published in Hydrol. Earth Syst. Sci. Discuss.: 15 November 2011

Revised: 21 March 2012 - Accepted: 25 March 2012 - Published: 11 April 2012

\begin{abstract}
The magnitude and timing of deep drainage and salt leaching through clay soils is a critical issue for dryland agriculture in semi-arid regions $\left(<500 \mathrm{~mm} \mathrm{yr}^{-1}\right.$ rainfall, potential evapotranspiration $\left.>2000 \mathrm{~mm} \mathrm{yr}^{-1}\right)$ such as parts of Australia's Murray-Darling Basin (MDB). In this rare study, hydrogeological measurements and estimations of the historic water balance of crops grown on overlying Grey Vertosols were combined to estimate the contribution of deep drainage below crop roots to recharge and salinization of shallow groundwater. Soil sampling at two sites on the alluvial flood plain of the Lower Namoi catchment revealed significant peaks in chloride concentrations at $0.8-1.2 \mathrm{~m}$ depth under perennial vegetation and at $2.0-2.5 \mathrm{~m}$ depth under continuous cropping indicating deep drainage and salt leaching since conversion to cropping. Total salt loads of 91-229 $\mathrm{tha}^{-1} \mathrm{NaCl}$ equivalent were measured for perennial vegetation and cropping, with salinity to $\geq 10 \mathrm{~m}$ depth that was not detected by shallow soil surveys. Groundwater salinity varied spatially from 910 to $2430 \mathrm{mS} \mathrm{m}^{-1}$ at 21 to $37 \mathrm{~m}$ depth $(N=5)$, whereas deeper groundwater was less saline $\left(290 \mathrm{mS} \mathrm{m}^{-1}\right)$ with use restricted to livestock and rural domestic supplies in this area. The Agricultural Production Systems Simulator (APSIM) software package predicted deep drainage of 3.3-9.5 $\mathrm{mm} \mathrm{yr}^{-1}(0.7-2.1 \%$ rainfall) based on site records of grain yields, rainfall, salt leaching and soil properties. Predicted deep drainage was highly episodic, dependent on rainfall and antecedent soil water content, and over a $39 \mathrm{yr}$ period was restricted mainly to the record wet
\end{abstract}

winter of 1998. During the study period, groundwater levels were unresponsive to major rainfall events (70 and $190 \mathrm{~mm}$ total), and most piezometers at about $18 \mathrm{~m}$ depth remained dry. In this area, at this time, recharge appears to be negligible due to low rainfall and large potential evapotranspiration, transient hydrological conditions after changes in land use and a thick clay dominated vadose zone.

This is in contrast to regional groundwater modelling that assumes annual recharge of $0.5 \%$ of rainfall. Importantly, it was found that leaching from episodic deep drainage could not cause discharge of saline groundwater in the area, since the water table was several meters below the incised river bed.

\section{Introduction}

Water is a major limitation to plant growth in both native and agricultural systems in the semi-arid areas such as the western Murray-Darling Basin (MDB) of Australia. Average annual rainfall of $450-500 \mathrm{~mm}$ coupled with relatively large rates of potential evapotranspiration $(>2000 \mathrm{~mm}$ ) conspire to limit the quantity of water available for plant growth. In this area, the precipitation to potential evapotranspiration is 0.23 0.25 . Native ecosystems, with both perennial and ephemeral plants, have adapted to this and use almost all of the rain infiltrating the soil (Crosbie et al., 2010b; Abbs and Littleboy, 1998). Therefore, in soils of high water holding capacity, 
such as the Vertosols of North Western NSW, deep drainage below the plant root zone is usually close to zero. In contrast, annual crop-fallow sequences generally use less water over the long term, resulting in increased surface run-off and deep drainage.

When native vegetation is replaced by annual crops with intervening periods of fallow to replenish soil water reserves, drainage generally increases, resulting in mobilisation of salt and other contaminants stored in the soil and ultimately increased recharge to groundwater. The latter effect is beneficial if fresh recharge occurs to depleted aquifers, but in many areas with saline clayey soils, it can be problematic if shallow water tables rise with increased saline discharge into surface systems (Stauffacher et al., 1997). Where chloride occurs at toxic concentrations within the plant root zone, from a threshold of approximately $250 \mathrm{mg} \mathrm{kg}^{-1}$ to highly toxic levels $>1500 \mathrm{mg} \mathrm{kg}^{-1}$, roots, depending on the concentration of chloride, are progressively unable to penetrate salt laden soil and therefore cannot access stored soil water and nutrients (Dang et al., 2008). Deep drainage through Vertosols can be highly saline with potential implications for water resources. For example, Gunawardena et al. (2011) reported lysimeter leachate salinity of up to $2500 \mathrm{mS} \mathrm{m}^{-1}$ at sites in the upper Murray-Darling Basin of Queensland.

In the past, it was typically assumed that deep drainage in heavy clay soils was negligible under dryland conditions in the northern plains of the MDB (Hearn, 1998). Low hydraulic conductivity of these alluvial sediments (derived from weathering of Tertiary age volcanics) lead to deep drainage being ignored in the Basin Salt Audit (SKM, 2010). However, estimates from crop water balance modelling based on extensive field data indicate that deep drainage under continuous wheat cropping on Vertosols increased from 30 to $\sim 100 \mathrm{~mm} \mathrm{yr}^{-1}$ (4.8-13.3\% of rainfall) as rainfall increased from 625 to $750 \mathrm{~mm} \mathrm{yr}^{-1}$ moving up the Liverpool Plains Catchment (Ringrose-Voase et al., 2003). Deep drainage from dryland agriculture on the widespread grey Vertosols with saline subsoils may well be an important contributor to saline discharge into agriculturally and ecologically sensitive areas; possibly more so than irrigated agriculture which occupies only $3 \%$ of the Namoi catchment (Vervoort et al., 2003).

Deep drainage, generally a small proportion of the total water balance, is often assumed to be equal to recharge, as for example Abbs and Littleboy's (1998) deep drainage simulations for the Upper Namoi. A soil-vegetation-atmospheretransfer model WAVES was used by Vervoort et al. (2003) to compare deep drainage and groundwater levels under irrigated cotton near Narrabri in the Lower Namoi. However, non-specific input data were used, and no observations were available for verification. WAVES was also used to assess the sensitivity of recharge to climatic factors, assuming drainage below $4.0 \mathrm{~m}$ was equal to recharge (McCallum et al., 2010). Deep drainage below a perennial pasture on a "typical" Namoi soil was found to be $14 \mathrm{~mm} \mathrm{yr}^{-1}$ (1.8\% of average Namoi rainfall), an order of magnitude higher than Abbs and Littleboy (1998). All of these studies assumed that deep drainage was equal to recharge, and none provided an integrated surface to groundwater assessment for a specific paddock or site.

Integrated approaches using soil water models to calculate recharge as a calibrated input to groundwater models are available, but rarely applied. Soil water models typically generate deep drainage values as the water remaining after accounting for other components of the water balance (Ranatunga et al., 2008), while groundwater models are typically calibrated to observed groundwater levels with estimated hydraulic parameters and recharge as an input (Middlemis et al., 2000). For example, the MODFLOW groundwater model developed by Merrick (2001) for the Lower Namoi catchment reported that diffuse recharge from rainfall was a minor recharge source. Recharge inputs were set at $0.5 \%$ of rainfall in the southern half and $0.1 \%$ of rainfall in the northern half of the catchment.

Under some conditions, rapid leakage may occur to several meters depth through heavy clay soils (Acworth and Timms, 2009; Greve et al., 2010; Timms et al., 2002; Timms, 1997). An increase in groundwater salinity, possibly due to increased saline drainage through the alluvium, has been reported in irrigation areas of the Lower Namoi (Barret et al., 2006; Smithson, 2009) and several sites in the Upper Namoi where groundwater salinity appears to have increased during the 1990s possibly limiting beneficial use (Timms et al., 2010).

To our knowledge, there are limited data available on deep drainage, recharge and salinity in the semi-arid $\left(<500 \mathrm{~mm} \mathrm{yr}^{-1}\right.$ rainfall $)$ areas such as the Lower Namoi catchment. A classic field study by Kennett-Smith et al. (1994) included some Vertosol sites, while Tolmie et al. (2004) provided a range of deep drainage values for Vertosols. Crosbie et al. (2010a) reported clear relationships between deep drainage and factors such as soil clay content, land use and rainfall that earlier studies were unable to develop, although this review apparently was limited in the state of New South Wales (NSW), to two Vertosol sites. Crop yields in these western areas are highly dependent on using stored soil water efficiently, so deep drainage losses are of concern. Thus, the Lower Namoi is an excellent study area for assessing the importance of deep drainage and concomitant impacts on water quality in semi-arid regions. The main objective of this exploratory study was to determine if deep drainage under annual cropping might mobilize the many tonnes of salt stored in these soils, with potential consequences for downstream water users including natural ecosystems.

Here we report estimations of deep drainage from direct measurements of soil $\mathrm{Cl}$ and simulation of crop and soil systems using farmers' records of crop type and grain yields and historic weather data. Shallow aquifers were located and monitored by drilling and installation of continuously 
logged piezometers. The capacity of the overlying regolith to support deep percolation and store deep drainage was determined from undisturbed cores taken adjacent to piezometers. The potential for saline discharge from shallow aquifers into streams was assessed using a detailed topographic survey. The gaps (quantitative, spatial and temporal) between deep drainage estimated from agronomic water balances and estimations and assumptions of groundwater recharge are addressed to assess the possible links of deep drainage with groundwater systems. Site investigations and monitoring, farming records, information from long term NOW (NSW Office of Water) monitoring bores and BOM (Bureau of Meteorology) data are used as a basis for estimating deep drainage by numerical modelling.

\section{Study area}

The study was carried out on 2 sites on the Cryon plain, a remote area east of the township of Walgett, in the far west of the Namoi catchment, in the northern Murray Darling Basin of Australia (Fig. 1). No groundwater irrigated agriculture occurs this far west in the Namoi catchment, partly because groundwater supplies are relatively deep and saline (McLean, 2003). The study sites were located on the the mixed farming properties Denham (D piezometers) and Sefton Park (SP piezometers), about $12 \mathrm{~km}$ north of the Namoi River. Field work including soil testing and coring was carried out at the two sites during 2005, 2006 and 2007. Unconsolidated alluvial deposits of clay, silt, sand and gravel occur to a depth of about $110 \mathrm{~m}$ in this area. Grey Vertosols (Isbell, 2002) are the dominant soil type and are defined by surface self mulching with deep cracking on drying, clay content greater than $35 \%$, and slickensides at depth and the dominant colour is grey $(0-0.5 \mathrm{~m})$. Soil chemistry $(0-$ $3 \mathrm{~m}$ depth) (Young, 2009) showed strong alkaline reaction (pH8), a peak in EC $\left(100-300 \mathrm{mS} \mathrm{m}^{-1}\right)$ at 0.5 to $1.5 \mathrm{~m}$, moderately large CEC $\left(20-40 \mathrm{cmol}(+) \mathrm{kg}^{-1}\right)$ and high levels of exchangeable sodium (20-45\%,>1 m depth).

Rainfall is non-seasonal, but generally summer dominant. Potential evapotranspiration (Class A pan) is $>2000 \mathrm{~mm} \mathrm{yr}^{-1}$ and is greatest in the summer months of December to February. Mean annual rainfall is $480 \mathrm{~mm}$ at Walgett $(480 \mathrm{~mm}) 30 \mathrm{~km}$ to the west of the Denham site (BOM, http://www.bom.gov.au/climate/data). The Namoi River flows into the Barwon River at Walgett, approximately 20 and $30 \mathrm{~km}$ to the west of the Denham and Sefton Park sites respectively. As the altitude decreases from $220 \mathrm{~m}$ at Narrabri to $130 \mathrm{~m}$ at Walgett, the surface elevation gradient is $<1 \%$ (Young et al., 2002). The plains were covered with savannah woodland (Beadle, 1981) until clearing for wheat cropping in 1965 (Denham) and 1985 (Sefton Park).

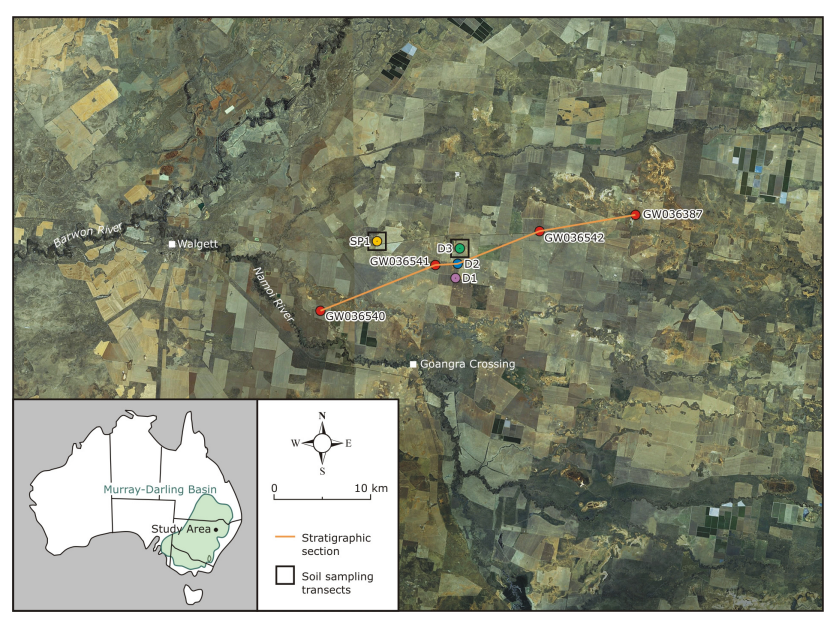

Fig. 1. Location map, showing the Namoi River, groundwater monitoring sites and location of stratigraphic section (Google earth image).

\section{Methods}

\subsection{Soil properties}

In May 2005, soil cores $(0-5 \mathrm{~m})$ were taken from adjacent continuously cropped and never cropped perennially vegetated sites at 2 locations. A tractor mounted hydraulically operated coring machine was used to obtain soil samples to $\leq 5 \mathrm{~m}$ depth using a $50 \mathrm{~mm}$ diameter Cr-Mo steel alloy tube with a $42 \mathrm{~mm}$ diameter cutting tip. Two locations (A and B) approximately $500 \mathrm{~m}$ apart were selected at each site (Denham and Sefton Park) each with adjacent grassland and cropping. Four cores, approximately $50 \mathrm{~m}$ apart, were taken along a transect on each land use at each location. The position of each core was randomly selected, irrespective of surface cracking, but permanent wheel tracks of farming machinery were avoided.

Soil cores were cut into depth sections $(0-0.1 \mathrm{~m}, 0.1-$ $0.3 \mathrm{~m}, 0.3-0.5 \mathrm{~m}$, etc. to $\leq 5 \mathrm{~m})$, air dried $\left(40^{\circ} \mathrm{C}\right)$, ground $<2 \mathrm{~mm}$, for chemical analysis. Bulk density $\left(\rho_{\mathrm{b}}\right)$ at field water content of each depth section, was calculated from the oven dry $\left(105^{\circ} \mathrm{C}\right)$ weight and dimensions of a $94 \mathrm{~mm}$ diameter core taken from each transect. Soil samples were analysed by the NSW Department of Primary Industries' Diagnostic and Analytical Services Environmental Laboratory, with the following methods: water soluble chloride and EC (Rayment and Higginson, 1992, method 5A1); exchangeable cations by ICP (method 15E1) and soil pH (method 4A1). Chloride data for deep drainage estimation were the means for each depth increment within each site, land use and location transect. Soil bulk density $\left(\rho_{\mathrm{b}}\right)$ was used to estimate saturated water content $\left(\mathrm{SAT}=\left[1-\rho_{\mathrm{b}} / 2.65\right] 100\right)$ and drained upper limit, assuming air filled porosity $(\phi)$ of 0.02 reducing to 0.005 at $5 \mathrm{~m}$ depth $\left(\mathrm{DUL}=\left([1-\phi]-\left[\rho_{\mathrm{b}}\right] / 2.65\right) 100 \%\right)$. The 
volumetric soil water content in the control native vegetation was assumed to be at the lower limit of available water (LL15).

\subsection{Stratigraphy and core testing}

Stratigraphic information was obtained from cutting returns during rotary mud drilling and geophysical bore logs. A Geovista $^{\text {TM }}$ logging system was used with bulk conductivity (EM39) and natural gamma sondes. Data was collected at $1 \mathrm{~cm}$ vertical increments in drill holes by running these sondes at a rate of $1-2 \mathrm{~m} \mathrm{~min}^{-1}$.

Two minimally disturbed cores were drilled using a split tube sampler mounted on the drilling rig, from 6-18 $\mathrm{m}$ depth at D1, and 5-17 m depth at D3. Intact $100 \mathrm{~mm}$ diameter cores were successfully recovered for $\rho_{\mathrm{b}}$ and hydraulic conductivity $(K)$ measurements. A field tensiometer (UMS) was inserted into a $10 \mathrm{~mm}$ diameter hole drilled into an intact sample from each meter of core, for tension and temperature measurements one and two hours after insertion. Two samples were taken per meter for $\rho_{\mathrm{b}}$. Two samples were also taken from each meter of core or core fragments and all traces of drilling mud and loose material were removed by trimming each sample with a sharp knife. The samples were then forced air dried $\left(40^{\circ} \mathrm{C}\right)$, ground $(<2 \mathrm{~mm})$ and analysed for chloride, EC and $\mathrm{pH}$ using the surface soil methods described in Sect. 3.1.

Core sections from D1 and D2 (12-17 m depth, $200 \mathrm{~mm}$ length) were placed into $250 \mathrm{~mm}$ long sections of rigid PVC pipe, $115 \mathrm{~mm}$ in diameter, contained within a snugly fitting outer PVC container with screw cap. Two-pack resin (Megapoxy $240 \mathrm{http}: / /$ www.megapoxy.com) was mixed and poured onto the core until the PVC pipe was full, and the core totally encased in resin. The outer container was capped and the sample was placed in a cool place until the resin had set, and then stored at $4{ }^{\circ} \mathrm{C}$.

Saturated hydraulic conductivity $\left(K_{\text {sat }}\right)$ was measured on these core sections sealed in PVC pipe using a modification of the method described by McKenzie et al. (2002). Prior to testing, each core section was cut into 3 smaller sections.

The core was placed, top end down, onto a vessel made from similar PVC pipe $(115 \times 100 \mathrm{~mm}$ and capped on the bottom end) containing a bed of coarse sand. The core was separated from the sand by a circle of thick filter fabric. The junction of the pipe sections was sealed with a rubber collar. An influent solution of $0.01 \mathrm{M} \mathrm{CaCl}_{2}$ was piped from an elevated reservoir providing a constant hydraulic head to the PVC vessel. During operation, the exposed upper surface of the core was kept moist, but not wet.

\subsection{Piezometer installation and groundwater quality}

Four nested piezometers were installed in cropped paddocks on Denham (D1, 2, 3) and one on Sefton Park (SP1) using the rotary drilling rig and mud methods (Table 1). The
D1 and D3 piezometers were located adjacent to the deep cores described in Sect. 3.2. Nested $50 \mathrm{~mm}$ diameter PVC piezometers were slotted ( $1.5 \mathrm{~m}$ screen with $1 \mathrm{~m}$ sump) in the shallow sandy material between 10 and $16 \mathrm{~m}$ depth (shallow screen), and in water bearing sandy silty sediments at 18 to $36 \mathrm{~m}$ depth. The Denham piezometers were on a north-south transect, 1.26 and $1.84 \mathrm{~km}$ apart (D1 to D2 and D2 to D3, respectively).

A GEOVISTA bore logging system obtained logs at $1 \mathrm{~cm}$ vertical increments. The natural gamma and EM39 logs were run at speeds of $2 \mathrm{~m} \mathrm{~min}^{-1}$, and due to relatively high salinity, the EM39 logs were run using lower sensitivity (Gain 2). The combination of natural gamma and EM39 logs provides the ability to discriminate between the effects of clay content and fluid EC anomalies.

Groundwater samples were obtained by purging bore water with either an air powered BENNET pump or $24 \mathrm{~V}$ MOONSOON pump until stable EC, $\mathrm{pH}$ and temperature were indicated by TPS meters and electrodes. These electrodes were calibrated with standard EC solutions each day.

An elevation survey to an accuracy of $\pm 5 \mathrm{~cm}$ using a Trimble RTK GPS was completed for all monitoring points, and in a north-south transect following the road to the Namoi River crossing at Goangra. The elevation of the river bank, the incised channel and the river level (8 January 2008) were recorded.

\subsection{Rainfall and groundwater levels}

Daily rainfall records were obtained from the Bureau of Meteorology (BOM) at Walgett council (BOM station 05026), Koothney north of Cryon (BOM station 52003) and from the Sefton Park property (F. Denya, personal communication, 2011). Since the BOM site is located approximately $30 \mathrm{~km}$ to the west of the Denham site, local property rainfall records were used for correlation where possible. The local residual mass rainfall curve indicates above average rainfall between April 1998 and 2001, and from February 2007 to the present, with very high rainfall in 1998 and 2010. From May 1998, the climate was influenced by a moderate La Niña event with above average rainfall (http://www.bom.gov.au/ climate/enso/feature/ENSO-feature.shtml).

Absolute groundwater pressures and atmospheric pressures were recorded every $15 \mathrm{~min}$ using Schlumberger Diver ${ }^{\circledR}$ and Baro Diver ${ }^{\circledR}$ loggers respectively, with manual dip measurements recorded periodically.

\subsection{Deep drainage estimation and simulation}

Deep drainage was estimated using three methods: transient chloride mass balance (SODICS), chloride front displacement and APSIM deep drainage modelling. 
Table 1. Summary of piezometers installed (1-2 September 2007), monitoring bore 36541 (NSW Office of Water), groundwater salinity (EC) and groundwater levels.

\begin{tabular}{lccccccc}
\hline Site & $\begin{array}{c}\text { Surface } \\
\text { elevation }\end{array}$ & $\begin{array}{c}\text { Screen } \\
\text { interval }\end{array}$ & $\begin{array}{c}\text { Piezo } \\
\text { height }\end{array}$ & $\begin{array}{c}\text { EC } \\
{\left[\mathrm{mS} \mathrm{m}^{-1}\right]}\end{array}$ & \multicolumn{2}{c}{ Groundwater level [m b.g.] } \\
\cline { 7 - 8 } & {$[\mathrm{m}$ AHD] } & {$[\mathrm{m}$ b.g. $]$} & {$[\mathrm{m}]$} & 23 Oct 2007 & 23 Oct 2007 & 29 Jan 2009 & 23 Jul 2009 \\
\hline D1s & 138.73 & $15.5-17$ & 0.39 & - & Dry & 17.3 & Dry \\
D1d & 138.74 & $22.5-24$ & 0.39 & 2240 & 18.95 & 18.92 & 18.91 \\
D2s & 139.15 & $14.5-16$ & 0.55 & - & Dry & - & - \\
D2d & 139.15 & $35.9-37.4$ & 0.55 & 1650 & 19.33 & - & - \\
D3s & 139.39 & $14.5-16$ & 0.55 & - & Dry & Dry & Dry \\
D3d & 139.41 & $38-41$ & 0.49 & 910 & 19.33 & 19.35 & 19.34 \\
SP1s & 136.15 & $10-11.5$ & 0.56 & - & Dry & Dry & 12.08 \\
SP1d & 136.13 & $21-22.5$ & 0.52 & 2430 & 16.98 & 17.04 & 17.05 \\
36541-1 & 135.78 & $33-36$ & 1.27 & 1645 & 18.1 & - & - \\
$36541-2$ & 135.78 & $57.3-60.3$ & 1.08 & 1000 & 20.32 & - & - \\
$36541-3$ & 135.78 & $89.6-95.6$ & 1.16 & 290 & 17.67 & - & - \\
\hline
\end{tabular}

Piezometers were installed 1-2 Sep 2007. Nested piezometers were installed in the same holes, piezo height is the steel monument height above ground level, m b.g. is metres below ground, AHD is Australian Height Datum, groundwater levels are manual dip measurements.

\subsubsection{Transient chloride mass balance}

Firstly, deep drainage was estimated from chloride massbalance using the SODICS software (Rose et al., 1979; Thorburn et al., 1991). The software was run for several depths and the most "sensible" result from the likely bottom of the crop root zone was selected (accounting for toxic layers of chloride). Chloride mass balance, including SODICS (Rose et al., 1979) software, has been widely used to predict deep drainage under irrigation and after conversion of perennial native vegetation to rainfed cropping (Walker, 1998; Young and McLeod, 2001; Silburn et al., 2011; Tolmie et al., 2011).

\subsubsection{Chloride front displacement}

Secondly, deep drainage was calculated from the difference in depths of the chloride peaks ( $\mathrm{Cl}$ FD) or "fronts" under cropped and control areas (Allison and Hughes, 1983; Walker et al., 1991). This method relies on the chloride profile retaining its shape during leaching and the movement of the profile is used to infer the rate of movement of water. For each site, total deep drainage since the change in land use was calculated as the difference in the drainable volume (Dr) = SAT-LL15 in the soil volume above the peak in the control area compared to that above the $\mathrm{Cl}$ peak in the cropped area. Here, we assume that for drainage to occur, soil water content $>$ DUL, and that soil water measured at the time of sampling may not $=$ DUL due to depletion since the time when drainage occurred due to extraction by crops or evaporation via deep cracks.

\subsubsection{Deep drainage simulation}

Thirdly deep drainage, water use and crop growth from farmers' records of crop sequences, yields and historic weather records was predicted with APSIM (Agricultural Production Systems Simulator). APSIM was parameterised to simulate cropping history, supplied by farmers, and changes in chloride profile data using historic weather data with deep drainage as output. The APSIM farming systems software consists of a series of interconnected modules, for plant growth, soil water and rooting depth where the crop types, fertiliser rates and planting rules are defined by the user (Keating et al., 2003). A set of biophysical modules simulates biological and physical processes in farming systems including rotations, residues, crop establishment and death and management issues responsive to weather or soil conditions. The model operates at a paddock scale (1-D) with a daily time step allowing it to capture episodic deep drainage events. The fate of rainfall is determined by potential evaporation, and the characteristics of the soil surface and the crop root zone. For example, if rain falls faster than it can infiltrate, then the module generates surface run-off. If rainfall infiltrates and tops up the soil water store faster than the crop can use water, driven by solar radiation, the water escapes below the crop root zone as deep drainage. Soil evaporation, during fallows in particular, were tuned so that the model closely simulated both the grain yield records and the chloride leaching observed in the field samples.

This study used the SoilWat2 module with APSIM, a "cascading bucket" model that is applicable to both Vertosols and the rigid soils of the Liverpool Plains (Ringrose-Voase et al., 2003). The model was developed from the CERES (Jones and Kiniry, 1986) and PERFECT models (Littleboy et al., 1992). Water redistribution in the profile is calculated by 


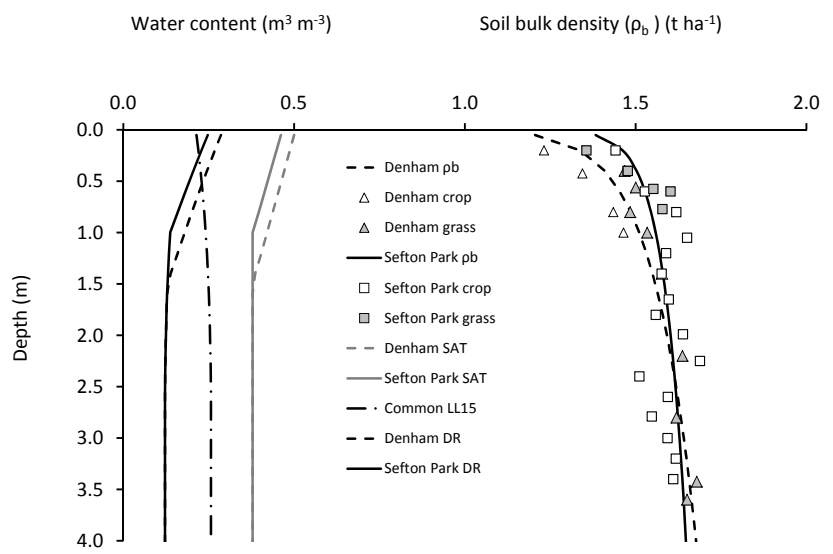

Fig. 2. Measured soil bulk density $\left(\rho_{\mathrm{b}}\right)$ and water holding capacity at "perennial vegetation lower limit" assumed $=-15$ bar (LL15) and derived water holding capacity at saturation (SAT) and drainable water capacity (DR).

allowing a fraction of the drainable water in each layer to drain to the next layer each day (Jones and Kiniry, 1986). For water contents below DUL, water movement depends upon the water content gradient between adjacent layers and the average water contents of the two layers. Soil chloride is redistributed within the soil profile as the result of both convective, or mass flow with water movement and diffusion processes.

For these APSIM SoilWat2 simulations the soil was divided into 26 layers of $0.1 \mathrm{~m}$ for the surface layer and $0.2 \mathrm{~m}$ for the remaining layers to $5.0 \mathrm{~m}$ depth. The SoilWat2 module requires a number of soil properties and water holding capacity inputs. The drained upper limit (DUL) was calculated from bulk density assuming material density of $2.65 \mathrm{t} \mathrm{m}^{-3}$ and air filled porosity at DUL of 0.05 . The volumetric soil water content in the perennially vegetated control areas were used as estimates of the moisture lower limit at $-15000 \mathrm{hPa}$ (LL15) (the samples were taken during an extended dry period). Saturated moisture (SAT) and air dried moisture content and permeability near saturation $(K$ at $-5 \mathrm{hPa})$ were also estimated from field information. Deep drainage was considered as the amount of water draining from the soil at $5.0 \mathrm{~m}$ depth.

\section{Results}

\subsection{Soil properties}

Soil properties to $\leq 5 \mathrm{~m}$ depth are presented in detail elsewhere (R. R. Young, personal communication, 2009) and are summarised here. The soil profiles were grey cracking clays (Grey Vertosols) with alkaline reaction ( $\mathrm{pH}$ 8-9) constant to $5 \mathrm{~m}$ depth. Bulk density $\left(\rho_{\mathrm{b}}\right)$ at field moisture content was large: 1.2 (Denham)-1.4 (Sefton Park) near the surface, increasing to a constant value of 1.6 at $1.0-1.5 \mathrm{~m}$ (Fig. 2). Despite differences in field water content, $\rho_{\mathrm{b}}$ was not apparently different between land uses. Cation exchange capacity (CEC) was high throughout the profile with a small peak, $\sim 40 \mathrm{cmol}(+) \mathrm{kg}^{-1}$, at $\sim 1 \mathrm{~m}$. The soils are highly sodic (exchangeable $\mathrm{Na} / \mathrm{CEC} \% \sim 10 \%$ at the surface increasing to $30-50 \%$ at $3 \mathrm{~m}$ depth).

Chloride increased to phytotoxic levels $\left(1000 \mathrm{mg} \mathrm{kg}^{-1}\right.$ for durum wheat, Dang et al., 2008) by $\sim 1 \mathrm{~m}$, within the usual rooting depth of most annual crops. There were significant peaks in chloride concentrations at $0.8-1.2 \mathrm{~m}$ depth under perennial vegetation and at $2.0-2.5 \mathrm{~m}$ depth under continuous cropping indicating deep drainage and salt leaching since conversion to cropping (Fig. 3, note that chloride data are $\mathrm{kg} \mathrm{ha}^{-1}$ and have been adjusted for equal mass balance for land uses within each comparison). This assumption appears reasonable as there was little evidence for leaching below $5 \mathrm{~m}$.

Despite the difference in the depth of salt peaks, leaching had not been to the extent that significant differences were detected in salt load under $(<5 \mathrm{~m})$ cropping and perennial vegetation. The average salt loads $\left(\mathrm{t} \mathrm{NaCl}\right.$ equivalent ha ${ }^{-1}$ in 0-5 m) calculated for transect 1 and 2, respectively were Denham cropping, 91, 140; Denham perennial vegetation, 91, 139; Sefton Park cropping, 163, 124; Sefton Park perennial vegetation, $229,99 \mathrm{tha}^{-1}$ of $\mathrm{NaCl}$. Total salt loads are approximately treble these values with large concentrations of sulphates (800-3600 mg kg${ }^{-1}$ ) and carbonates between 1 and $3 \mathrm{~m}$ depth.

The water content of soil under cropping was larger than that under perennial vegetation for some depth. The depth at which the water content of cores from perennial vegetation and cropping converged was deemed to be the depth of the wetting front. The wetting front was identified at $2.5 \mathrm{~m}$ at Sefton Park and $5.0 \mathrm{~m}$ at Denham where cropping began approximately $20 \mathrm{yr}$ earlier (Fig. 3). Bulk density, average LL15 and derived values for SAT and Dr were used in transient $\mathrm{Cl}$ mass balance (SODICS) and chloride front displacement ( $\mathrm{Cl} F D)$ calculations of deep drainage.

\subsection{Stratigraphy and core testing}

The stratigraphic section (Fig. 4) shows alluvial sediments across approximately $30 \mathrm{~km}$ from west to east across the Cryon plain. There is about $13 \mathrm{~m}$ of elevation change over this distance, as the elevation survey confirmed an east-west gradient of about $0.04 \%$ in the Cryon area. The section shows lenses of sand and gravel at 12 to $28 \mathrm{~m}$ below ground (the Narrabri Formation), and sand gravel aquifer from 40 to $86 \mathrm{~m}$ below ground (the Gunnedah Formation). A confining layer of clay with a thickness of almost $30 \mathrm{~m}$ separates this middle aquifer from the underlying Cubbaroo Formation, underlain by shale bedrock (NOW bore stratigraphy e.g. GW036541 on Fig. 4). 

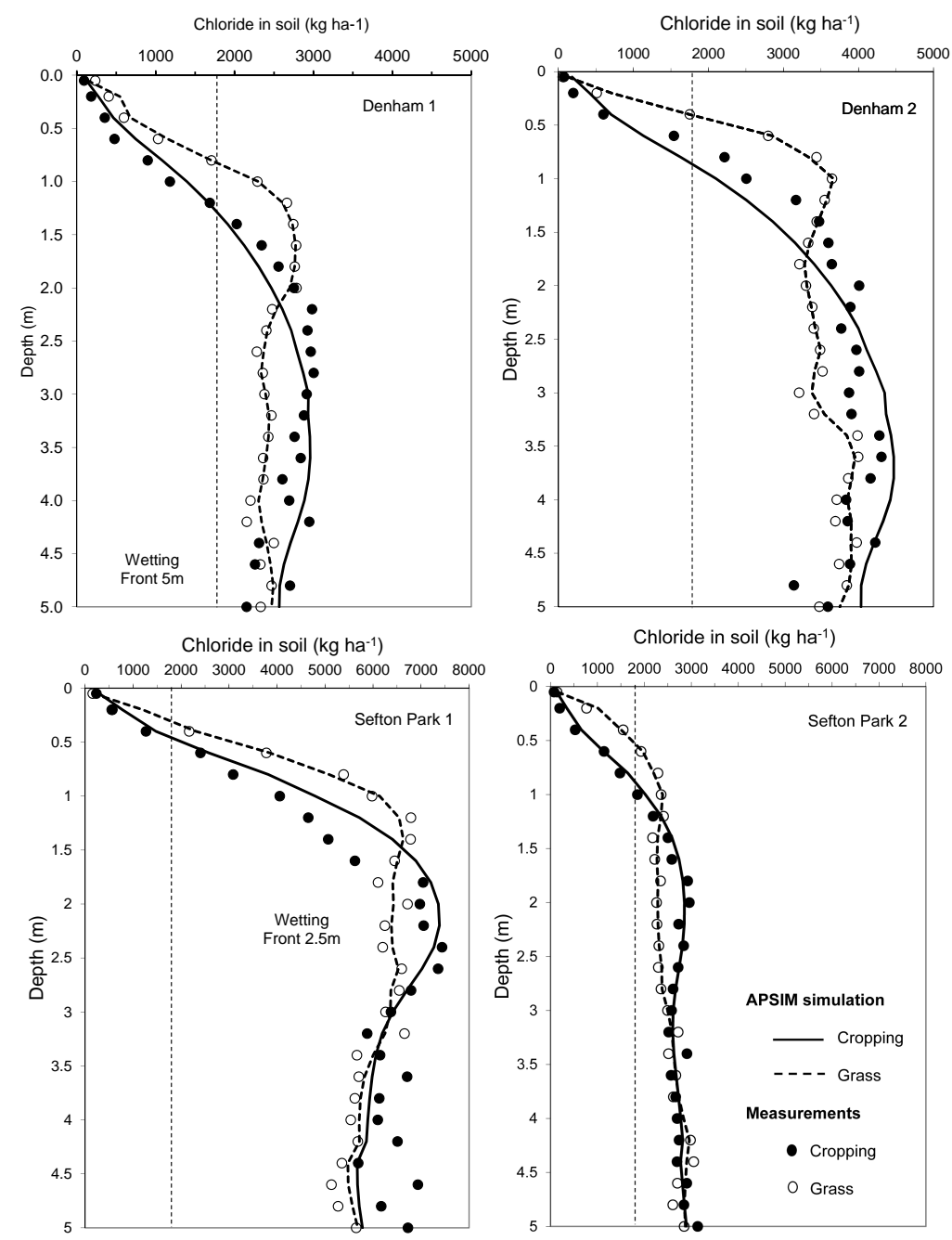

Fig. 3. Measured and APSIM simulations of normalised chloride in soil $\left(\mathrm{kg} \mathrm{ha}^{-1}\right)$ with depth at (a-b) Denham and (c-d)Sefton Park for cropping and grass control. The $50 \%$ reduction in water extraction for durum wheat is shown at $1000 \mathrm{mg} \mathrm{kg}^{-1}$ soil chloride at $1.0 \mathrm{~m}$ depth (Dang et al., 2008), equivalent to $1800 \mathrm{~kg} \mathrm{ha}^{-1}$ assuming bulk density of $1.5 \mathrm{t} \mathrm{m}^{-3}$ and have been adjusted for equal mass balance for land uses within each comparison.

Bulk density $\left(\rho_{\mathrm{b}}\right)$ of the cored sediments, near D1 and D3, underlying the top soil varied from $1.4-2.0 \mathrm{t} \mathrm{m}^{-3}$ (average 1.7, $N=35$ ), reflecting textural changes with no clear trend with depth (Fig. 5). Gravimetric moisture $\left(\theta_{\mathrm{g}}\right)$ varied from 0.16 to $0.30 \mathrm{~g} \mathrm{~g}^{-1}$ (average $0.22 \mathrm{~g} \mathrm{~g}^{-1}, N=36$ ). Tension values at $1 \mathrm{~h}$ varied substantially $(-13$ to $-1552 \mathrm{hPa}$, average $-559 \mathrm{hPa}, N=37$ ) but on average indicated relatively high suctions.

The potential storage space, i.e. air space $\left(V_{\mathrm{a}}\right)$, in the sediments for future deep drainage was estimated based on available information. The calculated air space $\left(V_{\mathrm{a}}=\left[1-\rho_{\mathrm{b}} / \rho_{\mathrm{s}}\right]-\left[\rho_{\mathrm{b}} \times \theta_{\mathrm{g}}\right]\right)$ or pore volume available for storage of additional deep drainage appears to be less than zero (Fig. 6a), if particle density, $\rho_{\mathrm{s}}=2.65 \mathrm{t} \mathrm{m}^{-3}$, the usual assumed value (Cresswell and Hamilton, 2002). Likely errors in the measurement of $\rho_{\mathrm{b}}$ were insufficiently large to produce such anomalies in $V_{\mathrm{a}}$. If the smallest estimates of $V_{\mathrm{a}}$ are assumed to be $\sim$ zero, so allowing the remainder positive volumes, then $\rho_{\mathrm{s}} 2.9-3 \mathrm{t} \mathrm{m}^{-3}$ (Fig. 6b), values that are likely to be overestimated. Then, unless $\rho_{\mathrm{s}}$ actually varied substantially from sample to sample the largest likely average values of $V_{\mathrm{a}}$ in core D1 was $<0.053 \mathrm{~m}^{3} \mathrm{~m}^{-3}$ and $\mathrm{D} 3$ was $<0.017 \mathrm{~m}^{3} \mathrm{~m}^{-3}$. Naturally high bulk conductivity of sediments at the piezometer and core sites was evident from EM39 logs (Fig. 5). Although there was variation between sites, the highest values $\left(46.3 \mathrm{mS} \mathrm{m}^{-1}\right)$ were recorded at $2-$ $4 \mathrm{~m}$ depth at site D1, with high values also at $15-26 \mathrm{~m}$ depth. Natural gamma activity indicated a relatively homogeneous clay between $2-10 \mathrm{~m}$ at D3 and $1-6 \mathrm{~m}$ at D1. The sediment appears to be relatively homogeneous on a scale of meters, since the downhole bulk conductivity logs at site D3 (Fig. 6) are almost identical from the surface to $16 \mathrm{~m}$ depth for the 


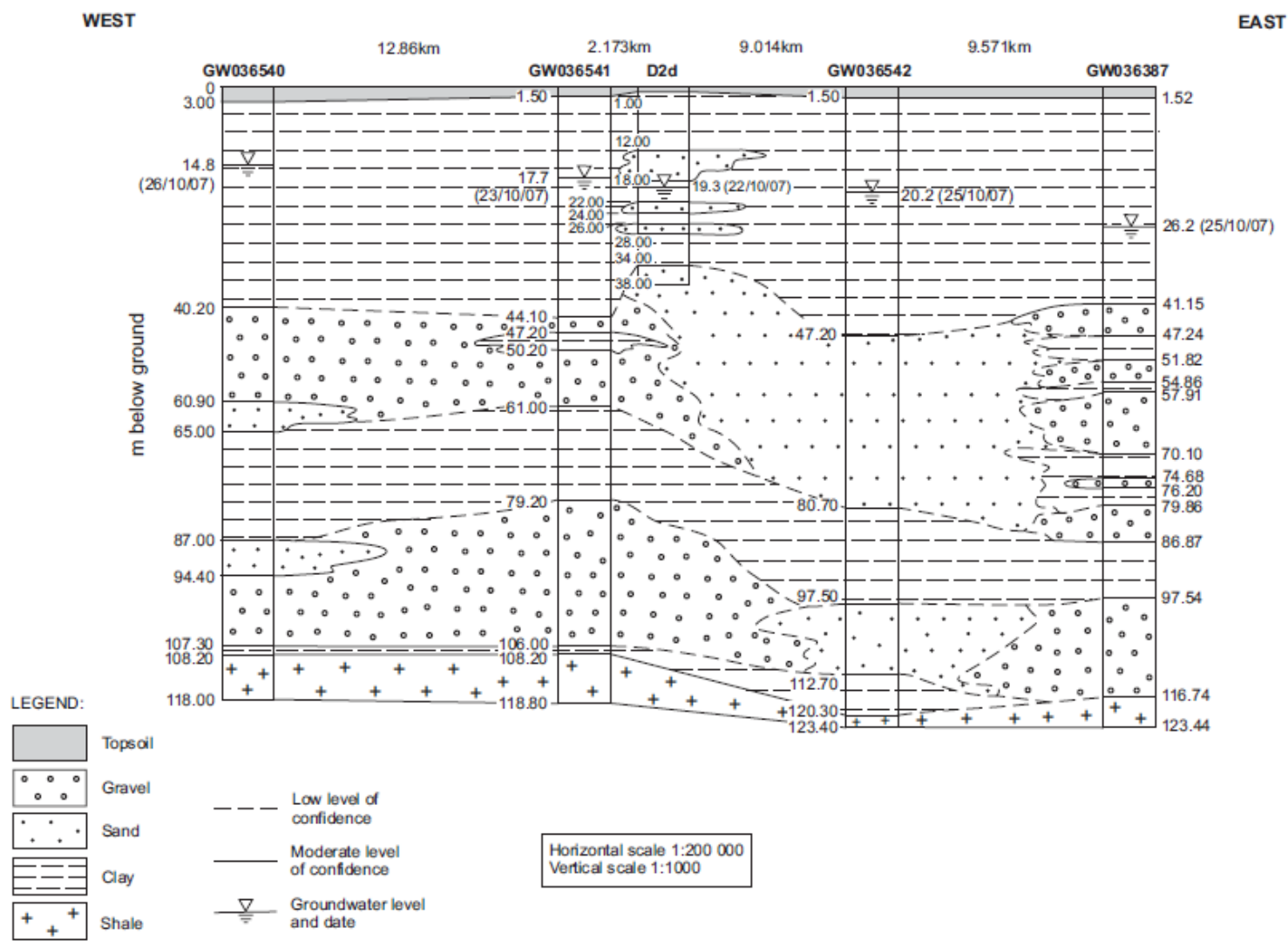

Fig. 4. Stratigraphic transect from west to east (location shown on Fig. 1), through the Denham monitoring piezometer site.

piezometer and core holes that are were located $5 \mathrm{~m}$ apart. However, there are significant stratigraphic heterogeneity observed at bores that are located more than a few metres apart (Figs. 4 and 5).

Salt content generally decreased with depth (1800 to $400 \mathrm{mg} \mathrm{kg}^{-1}$ ), from relatively high values at $2-5 \mathrm{~m}$ depth, except at $15 \mathrm{~m}$ depth associated with more clayey sediments (Fig. 5). Chloride and electrical conductivity (EC) were positively correlated and to a lesser extent, with soil moisture (Fig. 5). The higher salt storage in shallow soils and sediments was also observed in groundwater. Groundwater salinity (Table 1) varied spatially from 910 to $2430 \mathrm{mS} \mathrm{m}^{-1}$ at 21 to $37 \mathrm{~m}$ depth $(N=5)$. Deeper groundwater was less saline $\left(290 \mathrm{mS} \mathrm{m}^{-1}\right)$.

Tests of $K_{\text {sat }}$ were successful only on some core sections with a large hydraulic gradient. A relatively large vertical hydraulic gradient of 3 ( $0.3 \mathrm{~m}$ head over $0.1 \mathrm{~m}$ core section) applied to 14 core sections was insufficient to saturate cores and produce transmission of solute over periods of 14 to 35 days. A larger vertical hydraulic gradient of $18(1.86 \mathrm{~m}$ head over $0.1 \mathrm{~m}$ core section) applied to 10 cores over periods of 2 to 35 days, saturated 3 cores (D1, 12-13 m and 16-17 m depth; D2, 12-13 m) with subsequent transmission rates of $0.0040,0.0006$ and $0.0046 \mathrm{~mm} \mathrm{~h}^{-1}$, respectively. The equivalent $K_{\text {sat }}$ values are $6 \times 10^{-11} \mathrm{~m} \mathrm{~s}^{-1}$ for D1, 12-
$13 \mathrm{~m}, 9 \times 10^{-12} \mathrm{~m} \mathrm{~s}^{-1}$ for $16-17 \mathrm{~m}$ and $6 \times 10^{-11} \mathrm{~m} \mathrm{~s}^{-1}$ for D2, 12-13 m depth. However, the impact on $K_{\text {sat }}$ of swelling (under laboratory conditions) in the absence of the confining stress found at depth in the field is unknown. Hydraulic conductivity for unsaturated conditions would be expected to be significantly less than these $K_{\text {sat }}$ measurements.

When dissected, the cores for which $K_{\text {sat }}$ measurements were not successful were found to have become wet around 20-30 $\mathrm{mm}$ into the core and had swollen such that the core material protruded $2-3 \mathrm{~mm}$ from the resin and PVC pipe. The lack of flow through all but 3 cores, even with high hydraulic gradients and lengthy testing times, indicates that the hydraulic conductivity of these sodic clays is very low. Advanced permeability testing methods are required for these materials to apply stress equivalent to the core depth, to match in-situ porosity and controlling swelling while allowing for variable moisture content.

\subsection{Surface and groundwater levels}

The relative elevation of bores, piezometers and the nearby Namoi River showed that groundwater levels are located approximately $10 \mathrm{~m}$ below the stream bed (Fig. 7). This indicates that the Namoi River either is losing water or is hydraulically disconnected from groundwater at Goangra 


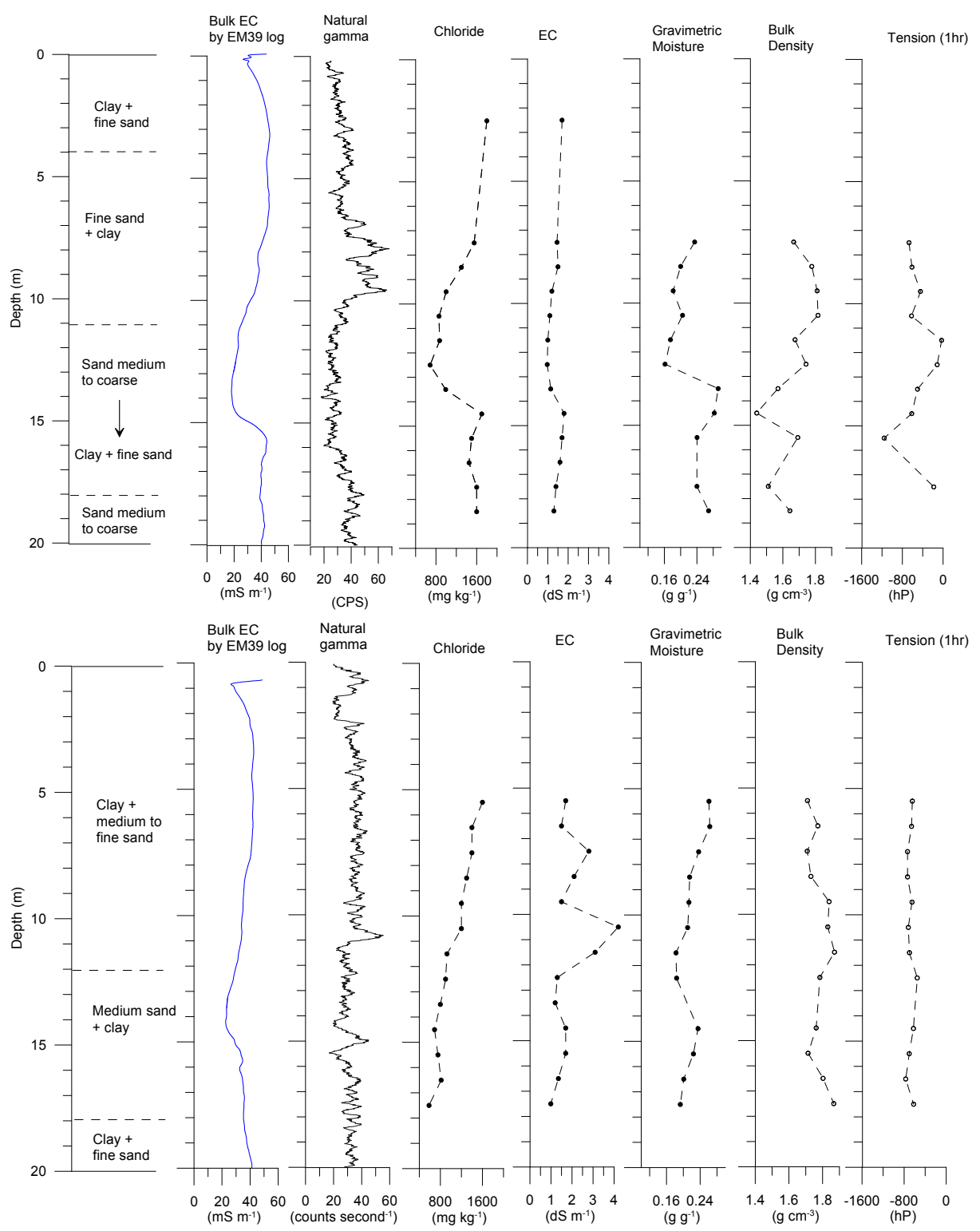

Fig. 5. Downhole sediment measurements showing bulk electrical conductivity and natural gamma logs, and core measurements including soil:water 1:5 electrical conductivity, chloride, water content, bulk density and tension for the (a) D1 site and (b) D3 site.

crossing, depending on the bed and bank permeability. That is, the river could be losing-connected, or losingdisconnected. Under these conditions, discharge of saline groundwater in the local area is not possible, but could be an issue further downstream.

Shallow piezometer screens (16 to $18 \mathrm{~m}$ depth) remained dry throughout the study period with one exception, and negligible groundwater level changes occurred in the piezometer screens between 22 and $42 \mathrm{~m}$ depth. Confined groundwater conditions were indicated by levels above the screen intakes and low barometric efficiencies of $30 \%$ for D1d and $18 \%$ for D2d (Timms et al., 2010). Groundwater levels in confined aquifers below the study area have been stable since
1984 (Fig. 8). Manual groundwater dip data, collected approximately four times per year do not show response to rainfall events in shallow screens, or any evidence of significant groundwater extraction from the deep screens (GW036540 and GW036541).

Automated logger data was captured for two large $(>70 \mathrm{~mm})$ rainfall events at selected sites. During Event 1, $70 \mathrm{~mm}$ fell over 8 days at the Walgett BOM station commencing on 19 December 2007, compared with rainfall at Sefton Park homestead of $81 \mathrm{~mm}$ over 3 days and $83 \mathrm{~mm}$ over 4 days recorded at the Koothney BOM station.

Event 1 resulted in a maximum groundwater level increase of $0.09 \mathrm{~m}$ on the same day of the event at $36 \mathrm{~m}$ and $95 \mathrm{~m}$ 


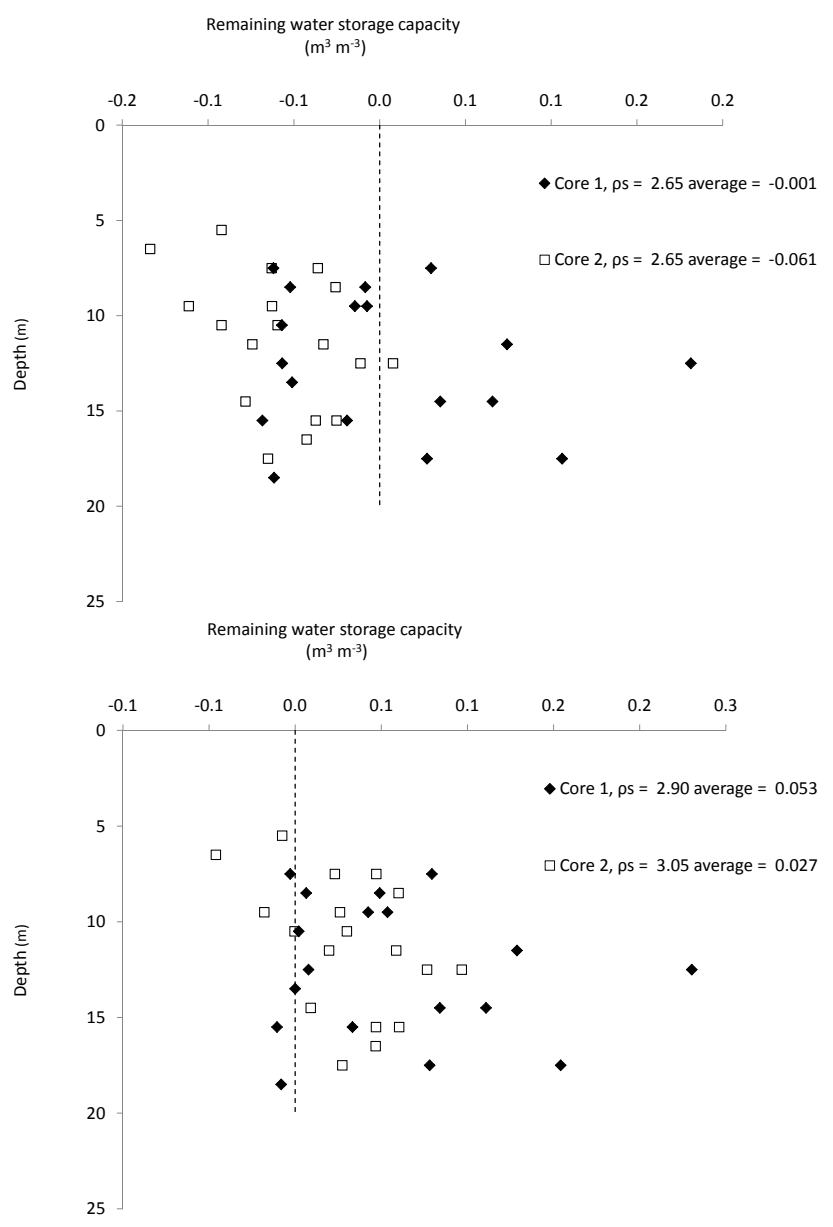

Fig. 6. Remaining water storage capacity for site D1 (Core 1) and site D3 (Core 2), calculated from bulk density, moisture content and (a) assumed particle density of $2.65 \mathrm{t} \mathrm{m}^{-3}$ and (b) assumed particle density of 2.90 and $3.05 \mathrm{t} \mathrm{m}^{-3}$.

depth (GW36541, screens 1 and 3). Groundwater levels increased in D1d by $0.04 \mathrm{~m}$ (Fig. 9) and SP1d by $0.05 \mathrm{~m}$ during this event and returned to average values soon afterwards. Equipment failure during 2007 unfortunately meant barometric data during the December 2007 event was not available.

During Event 2, on 14 February 2008, 112 and $116 \mathrm{~mm}$ rain was recorded at Sefton Park and Walgett BOM stations respectively. Over the 6 day event, totals of 189 and $191.4 \mathrm{~mm}$ were recorded at Sefton Park, and Walgett BOM stations, respectively. The Koothney BOM data is not considered reliable as $11.4 \mathrm{~mm}$ was recorded only on the 12 February 2008. Event 2 resulted in an immediate $0.04 \mathrm{~m}$ increase at SP1d, with groundwater levels returning to average values within days (Fig. 9). In contrast, a $0.107 \mathrm{~m}$ level increase was recorded at SP1s, commencing $15 \mathrm{~h}$ after the increase in SP1d. The levels in 5 SP1 gradually declined to pre-event levels over about 10 days.

Collection of water occurred in the sump below the screen intake, since the maximum level in SP1s was about $11.8 \mathrm{~m}$

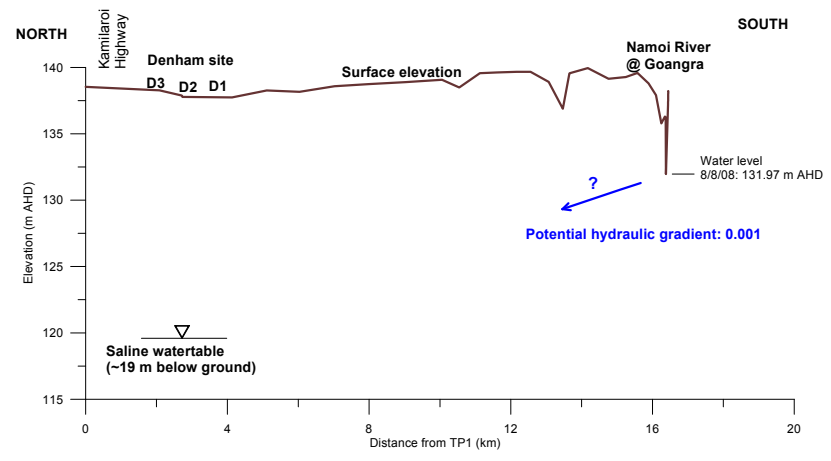

Fig. 7. Elevation transect from north to south through the Denham site to the Namoi River. The relative elevation of the saline water table at Denham, and the river level in January 2008 are shown.

below ground. The logger record of water in the sump was confirmed by a series of dry manual dip measurements before the event, and $0.1 \mathrm{~m}$ of water observed on 23 July 2009 (Table 1). It is significant that all three shallow piezometers at Denham were found to be dry on both these occasions, unfortunately multiple failures of Schlumberger Diver ${ }^{\circledR} \log -$ gers meant that no automated recordings were available from the shallow or deep piezometers.

\subsection{Estimated recharge rates}

Rainfall events of 80 to $190 \mathrm{~mm}$, almost half the annual rainfall, clearly do not result in significant groundwater level increases. A $107 \mathrm{~mm}$ level rise is equivalent to recharge of $1.5 \%$ of a $189 \mathrm{~mm}$ rainfall event (or $0.6 \%$ of 2009 rainfall total of $495 \mathrm{~mm}$ at Sefton Park), assuming a specific yield of 0.25 for the top of the saturated zone. However the actual recharge could be less due to preferential inflow around the bentonite seal that fills the annulus around the PVC pipe at $9 \mathrm{~m}$ depth. This estimate of recharge at just one of four locations during one major rainfall event is therefore subject to considerable uncertainty and requires further verification. If recharge is $<0.6 \%$ of annual rainfall during very wet years and is limited to localised areas of the plains, then the $50 \mathrm{yr}$ average recharge rate expressed as a long term average could therefore be $<0.01 \%$ of rainfall ( $<0.6 \%$ per year divided by 50 for a 1 in $50 \mathrm{yr}$ recharge event). Detection and verification of such a small (or negligible) rate of recharge for Grey Vertisols on the plains is a significant challenge.

\subsection{Deep drainage estimation and simulation}

\subsubsection{Transient chloride mass balance}

The SODICS software did not lend itself well to calculation of deep drainage from this chloride data. This was due to the negligible loss of salt (although downward displacement of the chloride peak under cropping was quite apparent) and root zone chloride concentrations under a cropped area being 


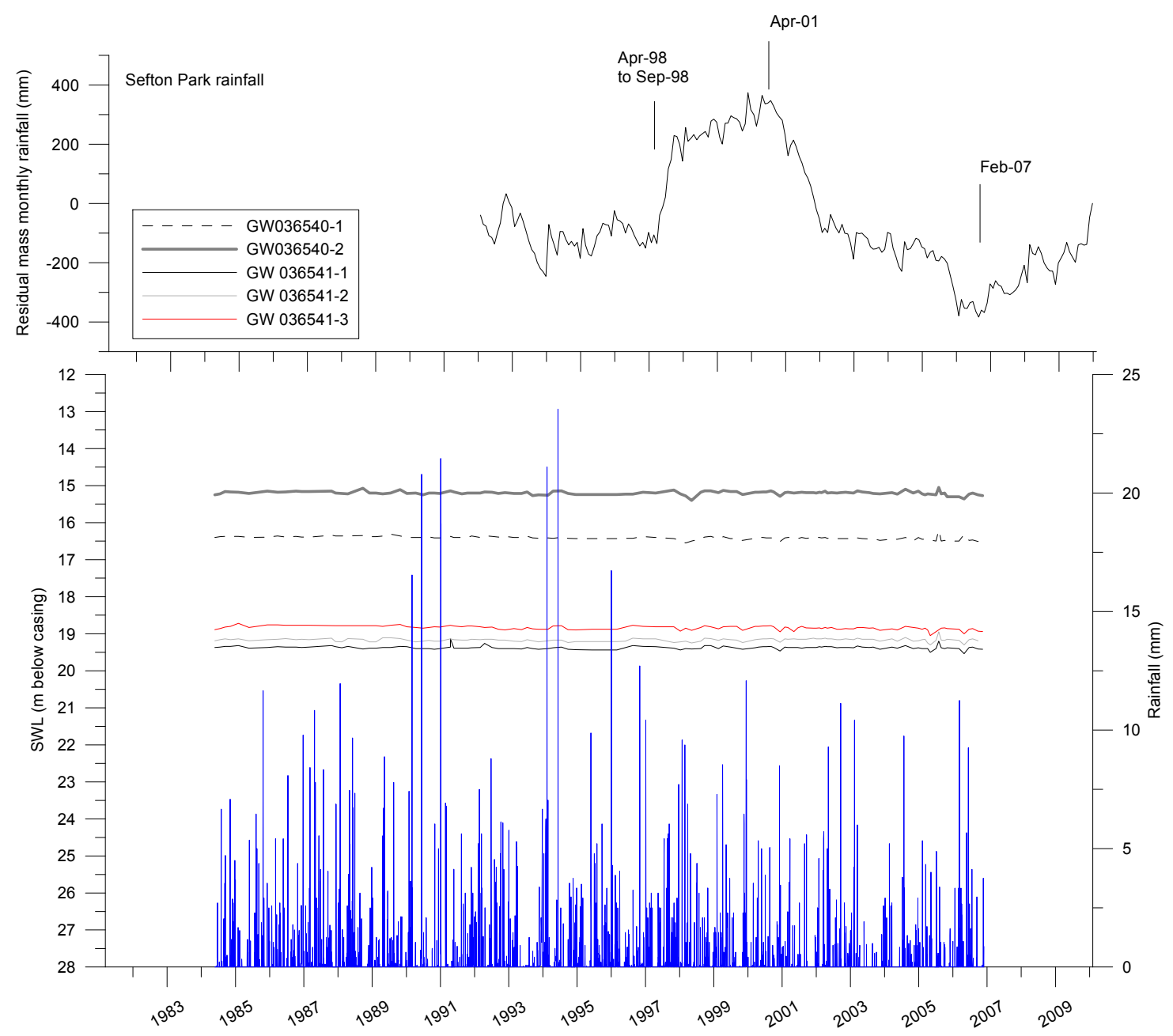

Fig. 8. (a) The residual mass curve for monthly rainfall at the Sefton Park and (b) groundwater levels (1985 to 2009) compared with daily rainfall.

Table 2. Deep drainage estimated using chloride mass balance, chloride front displacement and APSIM simulations of paddock records using historic weather data.

\begin{tabular}{|c|c|c|c|c|}
\hline & \multicolumn{2}{|c|}{ Denham } & \multicolumn{2}{|c|}{ Sefton Park } \\
\hline & Transect 1 & Transect 2 & Transect 1 & Transect 2 \\
\hline \multicolumn{5}{|c|}{ Chloride load: control, cropped (t ha ${ }^{-1}$ to $5 \mathrm{~m}$ depth) } \\
\hline & 52,56 & 73,82 & 138,95 & 49,66 \\
\hline \multicolumn{5}{|l|}{ Deep drainage } \\
\hline Time period & \multicolumn{2}{|c|}{ 1966-2004 } & \multicolumn{2}{|c|}{ 1986-2004 } \\
\hline SODICS $\left(m m y r^{-1}\right.$ at depth $\left.(m)\right)$ & $15(1.8)$ & $19(1.4)$ & $56(1.0)$ & $10(1)$ \\
\hline $\mathrm{Cl}$ FD (total, mm) & 128 & 171 & 82 & 80 \\
\hline$C l F D\left(m m y r^{-1}\right)$ & 3.2 & 4.3 & 4.1 & 4.0 \\
\hline APSIM (mm total) & \multicolumn{2}{|c|}{196} & \multicolumn{2}{|c|}{61} \\
\hline $\operatorname{APSIM}\left(m m y r^{-1}\right)$ & \multicolumn{2}{|c|}{5.0} & \multicolumn{2}{|c|}{3.2} \\
\hline
\end{tabular}




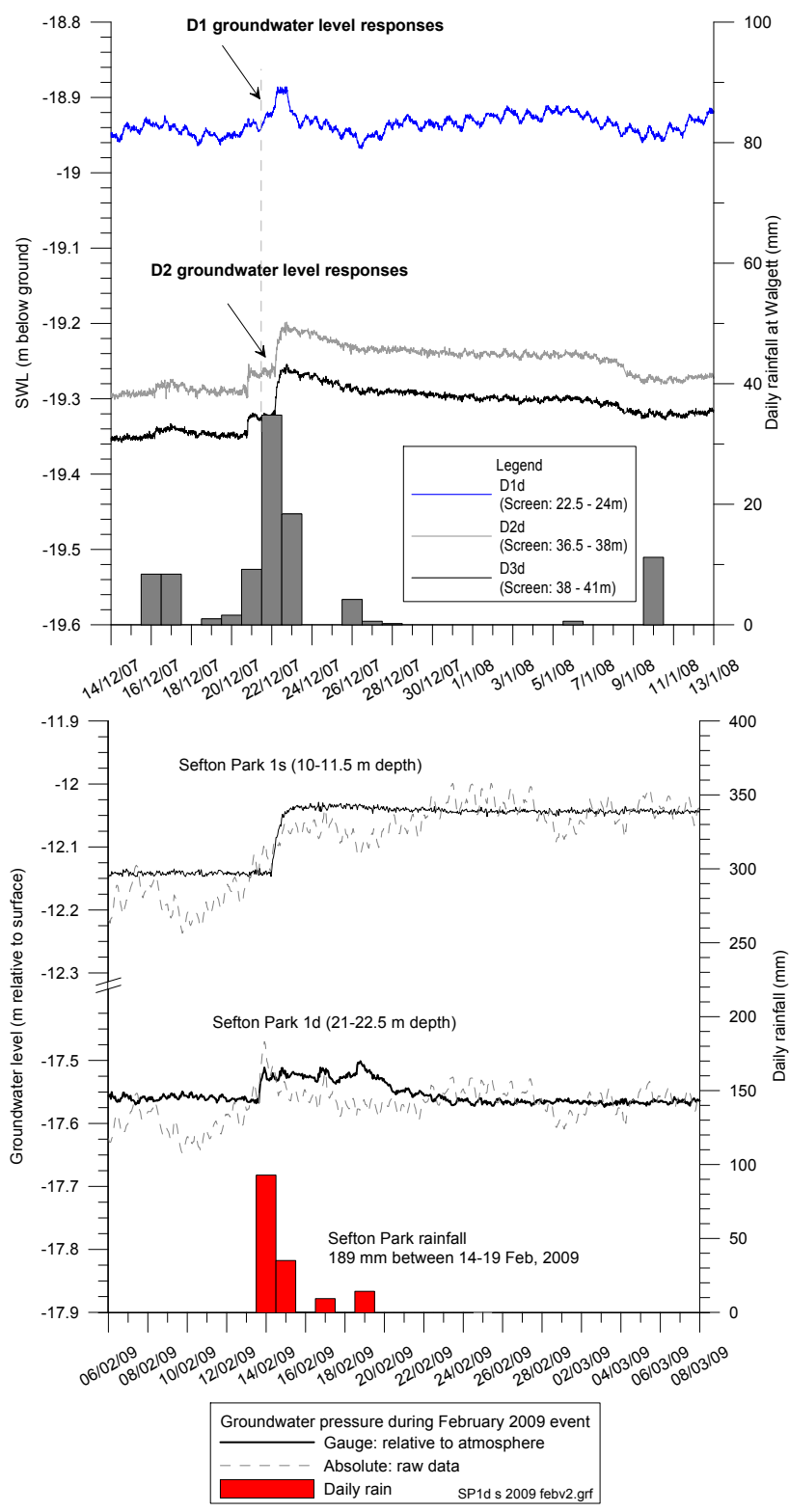

Fig. 9. Groundwater level variation at Denham monitoring piezometers for (a) December 2007 rainfall event, with absolute groundwater pressures recorded at $15 \mathrm{~min}$ intervals and (b) February 2009 event at Sefton Park with groundwater absolute and gauge pressures (based on daily rainfall at Sefton Park property).

greater than the control due to natural variation, resulting in negative deep drainage values (Table 2). Deep drainage at the bottom of the root zone (i.e. chloride $\geq 1000 \mathrm{mg} \mathrm{kg}^{-1}$ or $2.0 \mathrm{~m}$, whichever occurred first) ranged from $13-68 \mathrm{~mm} \mathrm{yr}^{-1}$ (Table 2). The lack of success of the SODICS method was despite considerable success when applied to data in higher rainfall areas where more leaching had occurred through Black Vertosols (Young and McLeod, 2001).
Table 3. Simulated deep drainage over time and as a proportion of rainfall 1966 to 2004.

\begin{tabular}{|c|c|c|c|}
\hline Deep drainage & Denham & Sefton Park & Time Period \\
\hline \multirow[t]{3}{*}{ Total (mm) } & 196 & - & 1966 to 2004 \\
\hline & 179.7 & 61 & 1986 to 2004 \\
\hline & 46.3 & 3.0 & 1986 to 2004 (except 1998) \\
\hline Average $\left(\mathrm{mm} \mathrm{yr}^{-1}\right)$ & 9.5 & 3.3 & 1986 to 2004 \\
\hline \multirow[t]{2}{*}{$\%$ of annual rainfall* } & 2.1 & 0.7 & 1986 to 2004 \\
\hline & 0.5 & 0.03 & 1986 to 2004 (except 1998) \\
\hline$\%$ of total in 1998 & 74.2 & 95.0 & \\
\hline$>10 \mathrm{~mm}$ (no. of years) & 2 & - & 1966 to 2004 ( $39 \mathrm{yr})$ \\
\hline$>2 \mathrm{~mm}$ (no. of years) & 12 & 1 & 1986 to 2004 (19yr) \\
\hline
\end{tabular}

* Walgett BOM data.

\subsubsection{Chloride front displacement}

The displacement of peaks in chloride concentration were at the same depths as the peaks in chloride rate $\mathrm{ha}^{-1}$ shown in Fig. 3. Deep drainage estimations using soil water holding capacity data were around $4 \mathrm{~mm} \mathrm{yr}^{-1}$ at both the sites (Table 2).

\subsubsection{Deep drainage simulations}

APSIM provided reasonably good simulations of actual grain yields (Fig. 10), although crop yield data were only available since 2000 for comparison with simulations. The model was initialised using $\mathrm{Cl}$ measurements from native vegetation (grass) and provided acceptable predictions of $\mathrm{Cl}$ movement over the period from clearing to 2004. Predicted values for cropping were close to average chloride values (Fig. 3) measured for four cores at each of the two locations at Denham and Sefton Park; providing confidence in predicted total deep drainage estimations. Elsewhere (R. R. Young and S. Harden, personal communication, 2009) have shown that the downward shift in $\mathrm{Cl}$ peaks is statistically significant.

Both observations and simulations show that the peak in soil salt has moved downwards from about $1.0 \mathrm{~m}$ to 2.0 and $3.0 \mathrm{~m}$ depth at these sites (Fig. 3). Greater salt mobilisation was apparent at the Denham site, presumably because it was cleared $20 \mathrm{yr}$ earlier than Sefton Park. Salts within the root zone are now lower in cropped areas, than in grassland 5 areas. However, total salt storage remains high to $5.0 \mathrm{~m}$ in the shallow cores (Fig. 3), and up to $10.0 \mathrm{~m}$ depth in the deep cores (Fig. 5).

Simulated deep drainage values are summarised in Table 3, and shown in comparison to annual cropping information in Fig. 10. Significant deep drainage occurred only during the wet periods with high antecedent soil moisture. Between 1966 and 2004, deep drainage of 57 and $133 \mathrm{~mm}$ (Sefton Park and Denham sites) occurred only during 1998 for paddocks with relatively moist soil. Significant deep drainage occurred 1 in $39 \mathrm{yr}$ at Denham, with deep drainage $>10 \mathrm{~mm}$ for 2 of $39 \mathrm{yr}$. Over a period of $19 \mathrm{yr}$, simulated deep drainage was equivalent to $0.7-2.1 \%$ of annual rainfall, or $0.03-0.5 \%$ of annual rainfall excluding 1998 data. The 

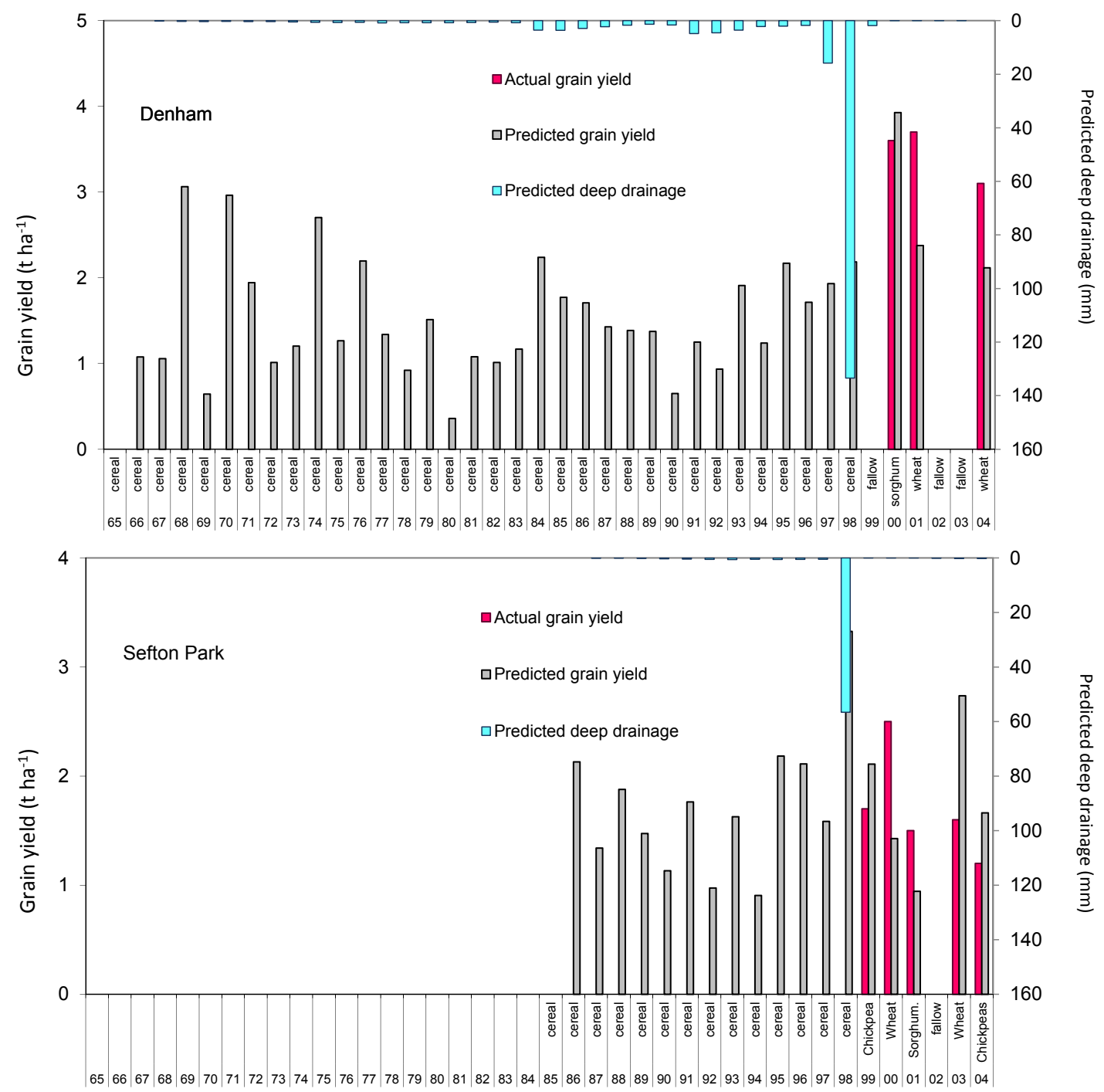

Fig. 10. Actual crop yields (pink), APSIM predicted crop yields (grey) and deep drainage (blue), compared to paddock records and grain yields for (a) Denham since 1966 and (b) Sefton Park since 1986. One significant deep drainage event is evident in 1998.

highly episodic nature of deep drainage is evident in that this occurred 1 in $39 \mathrm{yr}$ at Denham, with deep drainage $>10 \mathrm{~mm}$ for 2 of $39 \mathrm{yr}$. Over a period of $19 \mathrm{yr}$, simulated deep drainage was 0.7 and $2.1 \%$ of annual rainfall for Sefton Park and Denham sites respectively, or 0.03 and $0.5 \%$ of annual rainfall excluding 1998 data.

\section{Discussion and conclusions}

\subsection{Significance of deep drainage}

Displacement of chloride profiles under cropping compared to perennial vegetation control areas and water balance modelling show that water has drained below the plant root zone despite the low rainfall, high rates of evapotranspiration and relatively large water holding capacity of these Grey
Vertosols. However, simulation of paddock cropping history using historic weather data indicated that deep drainage was highly episodic and associated with very wet conditions. But most of the time, it was very small. Average annual deep drainage was in the order of 3-5 mm for the Sefton Park and Denham sites estimated either by the chloride front displacement or APSIM.

Groundwater modelling assumed constant annual recharge (Merrick, 2001), in contrast to the highly episodic nature of deep drainage. This assumption is appropriate considering the attenuation of episodic events through a $20 \mathrm{~m}$ thick vadose zone. A significant deep drainage eventoccurred 1 in $39 \mathrm{yr}$ at Denham, with deep drainage $>10 \mathrm{~mm}$ for 2 of $39 \mathrm{yr}$. The episodic nature of deep drainage is well known in the crop sciences (Crosbie et al., 2011; Lewis and Walker, 2002). For example, deep drainage simulations by Abbs and 
Littleboy (1998) using PERFECT over $108 \mathrm{yr}$ and for different dryland farming practices showed 54 of $108 \mathrm{yr}$ with no deep drainage.

\subsection{Groundwater response to large rainfall events}

This study has established that a water table occurs at $20 \mathrm{~m}$ depth at four exploratory drilling sites on the Denham and Sefton Park properties, and that there is generally no significant groundwater level response to large rainfall events. The lack of groundwater level response was to be expected given the large water holding capacity of the surface clays and the very low hydraulic conductivity limiting vertical flow through the vadose zone. This was in contrast to rapid groundwater level response in the Upper Namoi catchment (Timms and Acworth, 2005). The depth of the shallow saline water table had not previously been recorded in this area, as monitoring bores drilled in the 1960s had targeted high yielding deep aquifers and the shallowest monitoring bore screen was positioned at over $30 \mathrm{~m}$ depth in a semi-confined sand aquifer (GW036541-1).

High frequency groundwater level data reported in this study indicated that recharge is $<0.6 \%$ of annual rainfall and is limited to localised areas of the plains (1 of 4 sites, SP1s). Considering the uncertainties involved, the recharge is considered very small or negligible. The representative average recharge rate for Grey Vertsols on the plains, expressed as a $50 \mathrm{yr}$ average must therefore be $<0.01 \%$. Detection and verification of such a small (or negligible) rate of recharge is a significant challenge.

The lack of evidence for significant recharge is consistent with available natural isotope data for the area, although no studies of isotope variations after major rainfall have yet been attempted. Oxygen-18 and deuterium isotope values plotted in two groups relative to the Local Meteoric Water Line (Timms et al., 2008), with Group A (including D3 and GW36541-2) probably recharged in a wetter, cooler climate, whereas Group B (including sites D1, SP1 and D2) being relatively similar or relatively enriched compared with weighted modern rainfall values. Some additional evidence of very old groundwater is available from a detailed hydrogeochemical and isotope study in the Lower Namoi catchment (McLean, 2003). Carbon-14 activities for GW36542 of 3.9 and $1.1 \%$ modern carbon respectively for 75 and $101 \mathrm{~m}$ depth, corresponding to 22650 and $33530 \mathrm{yr}$ (apparent age). Although this was the only bore site sampled west of the irrigation area, there was clear evidence for increasing groundwater age downstream in the catchment, without significant modern recharge at depth.

\subsection{The gap between deep drainage and recharge}

Transient hydrological conditions in the sub-surface are anticipated where recent land use change may have increased deep drainage and where lateral flow pathways and moisture storage occur above the water table (Bond, 1998). Perennial vegetation at the Cryon sites was cleared for dryland wheat cropping in the 1960s. Whether the water draining beyond the root zone after a change to leakier land management ultimately recharges the groundwater system at some time in the future, will depend on the water storage capacity in the soil and regolith below the root zone, impediments to downward water movement which may create pockets of saturation/perched water tables and sub-surface lateral redistribution of water leading to discharge into lower lying surface waters or landscapes.

Deep drainage should be equal to recharge if there are no storage or lateral flows in the unsaturated/vadose zone, and a hydrological steady state has been achieved. For example, an increase in water storage in the vadose zone would indicate that deep drainage is greater than recharge of underlying groundwater. The estimates of storage capacity from the core samples are equivocal. At most, $\sim 4 \%$ of soil volume is air space ( $V_{\mathrm{a}} \approx 0.04 \mathrm{~m}^{3} \mathrm{~m}^{-3}$ or $800 \mathrm{~mm}$ over $20 \mathrm{~m}$ of sediment) remains as water storage capacity. At the least, there may be no water storage capacity $\left(V_{\mathrm{a}} \approx 0,\right)$ which, together with very low rates of hydraulic conductivity, may render much of the vadose zone hydrologically inactive and a barrier to groundwater recharge from leakage from overlying surface sediments. The gap between deep drainage and groundwater recharge estimates is due in part to the separation of scientific disciplines and limitations of 1-D models such as APSIM as recognised by Ringrose-Voase et al. (2003). If the total amount of water that could be stored between the surface and the water table at $20 \mathrm{~m}$ depth was in the order of $0.8 \mathrm{~m}$, then with a deep drainage rate of $\sim 10 \mathrm{~mm} \mathrm{yr}^{-1}$, it would take $\sim 80 \mathrm{yr}$ for the wetting front presently at 2.5 to $5 \mathrm{~m}$ depth to advance sufficiently to recharge water tables at $20 \mathrm{~m}$ depth. This estimate assumes a minimum hydraulic conductivity of $0.0001 \mathrm{~mm} \mathrm{~h}^{-1}$ in any layer and a relatively large deep drainage rate because of the widespread adoption of zero tillage cropping in North Western NSW which captures and conserves far more rainfall than previous systems. By comparison, studies of Vertosols in Queensland found deep drainage over the last 30 to $50 \mathrm{yr}$ was stored in the unsaturated zone indicating a long time lag between landuse change and groundwater response (Silburn et al., 2011; Silburn and Montgomery, 2008). Lag times between deep drainage and recharge in other soil types have been reported by Jolly et al. (1989) and Leaney et al. (2011).

However, drainage can occur beyond the wetting front towards the water table, even at constant soil moisture, by gravity if the moisture is above the DUL, and by a suction gradient that is downwards. Core data (Fig. 5) indicates that a significant suction gradient exists within the sedimentary layers with orientation both up and down, suggesting an additional impediment to downward flow in some layers. Considering all these factors, the proportion of deep drainage that becomes actual recharge is likely to negligible in this area of the Lower Namoi catchment. 


\subsection{Sediment heterogeneity and preferential flow}

Preferential flow, if verified, could be via heterogeneity within the sediment matrix, cracking, slickenside surfaces or leakage along the piezometer-soil interface. The sediment appears to be relatively homogeneous on a scale of meters, but varies between bores that are more than a few meters apart. Sediment heterogeneity at a scale hundreds of meters on this flood plain is consistent with the possibility of ancient channels (Young et al., 2002). The observation of water collecting in the sump of a previously dry piezometer (SP1s) after a $190 \mathrm{~mm}$ rainfall event could be significant, but is difficult to interpret. Independent confirmation, using geochemical and isotopic signatures is required to verify whether this observation was a direct result of recharge at depth.

\subsection{Salt storage and potential for mobilisation}

High salt storage to $10 \mathrm{~m}$ depth was measured at these sites with evidence for mobilisation of salt by deep drainage beneath crops. There were significant peaks in chloride concentrations at $0.8-1.2 \mathrm{~m}$ depth under perennial vegetation and at $2.0-2.5 \mathrm{~m}$ depth under continuous cropping indicating deep drainage and salt leaching since conversion to cropping. A similar range of total salt loads $\left(91-229 \mathrm{tha}^{-1} \mathrm{NaCl}\right.$ equivalent) were measured for both perennial vegetation and cropping.

The present annual rate of deposition, via rain and dryfall, of marine $\mathrm{NaCl}$ is $\sim 11.3 \mathrm{~kg} \mathrm{ha}^{-1}$ at Gunnedah in the Upper Namoi (Blackburn and McLeod, 1983). Accounting for the salt store in the top $10 \mathrm{~m}$ of up to $229 \mathrm{tha}^{-1}$, would require over $20000 \mathrm{yr}$ of aerial deposition by this mechanism, and assuming no leaching to groundwater. However, a significant proportion of salt storage is likely to be related to Aeolian dust deposits from inland Australia (rather than marine sources) that peaked approximately $13000 \mathrm{yr}$ ago in this area (Young et al., 2002). Leaching of accumulated chloride at toxic concentrations can only benefit crop growth by increasing the availability of soil water to crops (Dang et al., 2008). Figure 3 shows chloride concentrations with depth relative to the $50 \%$ yield reduction threshold for salinity in durum wheat (Dang et al., 2008). APSIM predictions suggest that the rate of deep drainage and leaching will substantially increase if zero tillage continuous winter cropping continues without improved water use efficiency and productivity. Water loss as deep drainage is doubled under continuous winter cropping using zero tillage practices compared with traditional cultivation practices (Young, 2009).

A small fraction of saline deep drainage mixing with relatively fresh groundwater or river water could have significant consequences for beneficial use and the environment. Groundwater salinity varied spatially from 910 to $2430 \mathrm{mS} \mathrm{m}^{-1}$ at 21 to $37 \mathrm{~m}$ depth (Table $1, N=5$ ). Deeper groundwater, with use restricted to livestock and rural domestic supplies in this area, was less saline $\left(290 \mathrm{mS} \mathrm{m}^{-1}\right)$ compared to seawater salinity of $5800 \mathrm{mS} \mathrm{m}^{-1}$. The EC of leachate from deep drainage was not measured at these sites, but over time, would add to the mass of salt in shallow groundwater.

\subsection{Implications for catchment management}

This study found that deep drainage may affect groundwater in the long term, but not the nearby Namoi River. The possible risk of discharge of saline groundwater from the Namoi catchment to surface water in the Darling catchment (Jolly et al., 1989) was not assessed in this study. Although it is very likely that deep drainage and mobilisation of subsoil salt will be greater under zero tillage cropping compared to native vegetation, there is no apparent risk of discharge into streams or onto low lying flood plains in the foreseeable future within the Namoi catchment. Groundwater moves slowly to the south-west, but cannot discharge to the surface because the Namoi River bed is located at least $10 \mathrm{~m}$ above the water table.

Surface waters in this area appear to be either losingdisconnected or losing-connected, depending on the permeability of the bed and bank sediments and the degree of saturation below the bed. In this area, deep drainage could matter most as lost production, since $1 \mathrm{~mm}$ is required for every $3-5 \mathrm{~kg} \mathrm{ha}^{-1}$ wheat yield. It is acknowledged however, that most of the time, deep drainage is sufficiently small that production losses would be negligible. A significant benefit of deep drainage is the leaching of salt from the crop root zone, likely to be large where salt stores are large, but it will take time and probably a series of wet seasons. The implications of increased salt leaching to the water table are not a primary concern this far west in the Namoi catchment where livestock are watered from much deeper artesian bores.

The substantial time lag for changes at the soil surface to affect groundwater, perhaps decades, could constitute an unseen threat to natural resources, but is also an opportunity to quantify small, gradual changes and to implement the necessary land management actions. Silburn and Montgomery (2008) for example report a time lag of 30 to $40 \mathrm{yr}$ for new equilibrium fluxes to establish in clayey soils of the northern MDB.

Integrated analyses of flow systems from the ground surface to the saturated zone are lacking, particularly over both dry and wet climatic periods. This paper is a contribution to linking the scientific disciplines of crop water balance and hydrogeology. Current work is extending this exploratory approach to saline risk areas by direct comparison of deep drainage and recharge measurements and models, combined with high resolution isotope and salinity measurements of groundwater and pore water in the vadose zone to detect possible changes over time. 
Acknowledgements. This work was funded by the National Action Plan for Salinity Australia) through the NSW Department of Primary Industries. We thank David and Fiona Denyer and Sandy Stump for site access and support, biometrical support provided by Steven Harden (DPI), and for technical support: Ross McLeod, Steven O'Brien (DPI), Maureen Schwarz (UNSW), Ian Cunningham (UNSW) and Anna Blacka (UNSW).

Edited by: Y. Fan

\section{References}

Abbs, K. and Littleboy, M.: Recharge estimation for the Liverpool Plains, Aust. J. Soil Res., 36, 335-57, 1998.

Acworth, R. I. and Timms, W. A.: Evidence for connected water processes through smectite dominated clays at Breeza, New South Wales, Aust. J. Earth Sci., 56, 71-86, 2009.

Allison, G. B. and Hughes, M. W.: The use of natural tracers as indicators of soil water movement in a temperate semi-arid region, J. Hydrol., 60, 157-173, 1983.

Barret, C., Williams, R. M., and Sinclair, P.: Groundwater chemistry changes due to mixing - Lower Namoi Valley, New South Wales, Proceedings of the 10th Murray-Darling Basin Groundwater Workshop, Canberra, 18-20 September 2006.

Beadle, N. C. W.: The vegetation of Australia, Cambridge University Press, Cambridge, Cambridgeshire, New York, 1981.

Blackburn, G. and McLeod, S.: Salinity of atmospheric precipitation in the Murray-Darling Basin Drainage Division, Australia, Aust. J. Soil Res., 21, 411-434, 1983.

Bond, W.: Part 3: Soil physical methods for estimating recharge, in: The Basics of Recharge and Discharge, edited by: Zhang, L., CSIRO Publishing, Collingwood, 1998.

Cresswell, H. P. and Hamilton, G. J.: "Chapter 3 Bulk density and pore space relations", in: Soil physical measurement for interpretation and land evaluation, edited by: McKenzie, N., Coughlan, K., and Cresswell, H., CSIRO Publishing, Collingwood, Australia, 2002.

Crosbie, R. S., Jolly, I. D., Leaney, F. W., Petheram, C., and Wohling, D.: Review of Australian groundwater recharge studies, CSIRO Water for a Healthy Country National Research Flagship, Canberra, 79 pp., 2010a.

Crosbie, R. S., Jolly, I. D., Leaney, F. W., and Petheram, C.: Can the dataset of field based recharge estimates in Australia be used to predict recharge in data-poor areas?, Hydrol. Earth Syst. Sci., 14, 2023-2038, doi:10.5194/hess-14-2023-2010, 2010 b.

Crosbie, R. S., McCallum, J., Walker, G., and Chiew, F.: Episodic recharge and climate change in the Murray-Darling Basin, Australia, Hydrogeol. J., 20, 245-261, doi:10.1007/s10040-0110804-4, 2011.

Dang, Y. P., Dala, R. C., Mayer, D. G., McDonald, M., Routley, R., Schwenke, G. D., Buck, S. R., Daniells, I. G., Singh, D. K., Manning, W., and Ferguson, N.: High subsoil chloride concentrations reduce soil water extraction and crop yield on Vertosols in north-eastern Australia, Aust. J. Agr. Res., 59, 321-330, 2008.

Greve, A., Andersen, M. S., and Acworth, R. I.: Investigations of soil cracking and preferential flow in a weighing lysimeter filled with cracking clay soil, J. Hydrol., 393, 105-113, 2010.

Gunawardena, T. A., McGarry, D., Robinson, J. B., and Silburn, D. M.: Deep drainage through Vertosols in irrigated fields measured with drainage lysimeters, Soil Res., 49, 343-354, 2011.

Hearn, A. B.: Summer rains on Vertosol Plains - A review of cotton irrigation research in Australia, Irrigation Association of Australia 1998 National Conference, Brisbane, 19-21 May 1998.

Isbell, R. F.: The Australian Soil Classification(revised edition) CSIRO, Australia, 2002.

Jolly, I. D.: Investigation into the potential for increased stream salinisation in the Darling Basin, CSIRO, Adelaide, 1989.

Jolly, I. D., Cook, P. G., Allison, G. B., and Hughes, M. W.:Simultaneous water and solute movement through an unsaturated soil following an increase in recharge, J. Hydrol., 111, 391-396, 1989.

Jones, C. A. and Kiniry, J. R.: CERES-Maize - a simulation model of growth and development, Texas A\&M University Press, College Station, Texas, 1986.

Keating, B. A., Carberry, P. S., Hammer, G. L., Probert, M. E., Robertson, M. J., Holzworth, D., Huth, N. I., Hargreaves, J. N. G., Meinke, H., Hochman, Z., McLean, G., Verburg, K., Snow, V., Dimes, J. P., Silburn, M., Wange, E., Brown, S., Bristow, K. L., Asseng, S., Chapman, S., McCown, R. L., Freebairn, D. M., and Smith, C. J.: An overview of APSIM, a model designed for farming systems simulation, Eur. J. Agron., 18, 267-288, 2003.

Kennett-Smith, A., Cook, P., and Walker, G.: Factors affecting groundwater recharge following clearing in the south-western Murray Basin, J. Hydrol., 154, 85-105, 1994.

Leaney, F., Crosbie, R., O’Grady, A., Jolly, I., Gow, L., Davies, P., Wilford, J., and Kilgour, P.: Recharge and discharge estimation in data poor areas: Scientific reference guide. CSIRO: Water for a Healthy Country National Research Flagship, 2011.

Lewis, F. M. and Walker, G. R.: Assessing the potential for significant and episodic recharge in southwestern Australia using rainfall data, Hydrogeol. J., 10, 229-237, 2002.

Littleboy, M., Silburn, D. M., Freebairn, D. M., Woodruff, D. R., Hammer, G. L., and Leslie, J. K.: Impact of soil erosion on production in cropping systems. I Development and validation of a simulation model, Aust. J. Soil Res., 30, 757-774, 1992.

McCallum, J. L., Crosbie, R. S., Walker, G. R., and Dawes, W. R.: Impacts of climate change on groundwater in Australia: a sensitivity analysis of recharge, Hydrogeol. J., 18, 1625-1638, 2010.

McKenzie, N., Coughlan, K., and Cresswell, H.: Soil physical measurement for interpretation and land evaluation, CSIRO Publishing, Collingwood, Australia, 2002.

McLean, W.: Hydrogeochemical evolution and variability in a stressed alluvial aquifer system: Lower Namoi River catchment, NSW, PhD Thesis, University of New South Wales, School of Biological Earth and Environmental Science, 2003.

Merrick, N. P.: Report on Lower Namoi Groundwater Flow Model - Calibration 19800-1998, Insearch Limited Report for the Department of Water and Energy, Sydney, 2001.

Middlemis, H., Merrick, N., and Ross, J.: Murray-Darling Basin groundwater flow modelling guideline, Murray-Darling Basin Commission, Canberra, 2000.

Ranatunga, K., Nation, E., and Barratt, D.: Review of soil water models and their application in Australia, Environ. Modell. Softw., 23, 1182-1206, 2008.

Rayment, G. E. and Higginson, F. R.: Australian laboratory handbook of soil and water chemical methods, Incarta Press, Melbourne, 1992. 
Ringrose-Voase, A. J., Young, R. R., Paydar, Z., Huth, N. I., Bernardi, A. L., Cresswell, H. P., Keating, B. A., Scott, J. F., Stauffacher, M., Banks, R. G., Holland, J. F., Johnston, R. M., Green, T. W., Gregory, L. J., Daniells, I., Farquharson, R., Drinkwater, R. J., Heidenreich, S., and Donaldson, S.: Deep Drainage under Different Land Uses in the Liverpool Plains Catchment, Report 3, Agricultural Resource Management Report Series, NSW Agriculture, ISBN 073471565 X, 2003.

Rose, C. W., Dayananda, P. W. A., Neilsen, D. R., and Biggar, J. M.: Long term solute dynamics and hydrology in irrigated slowly permeable soils, Irrigation Sci., 1, 77-87, 1979.

Silburn, D. M. and Montgomery, J.: Deep drainage under irrigated cotton in Australia: a review, in: WaterPAK - A guide for irrigation management in cotton, 2008.

Silburn, D. M., Tolmie, P. E., Biggs, A. J. W., Whish, J. P. M., and French, V.: Deep drainage rates of Grey Vertosols depend on land use in semi-arid subtropical regions of Queensland, Australia, Soil Res., 49, 424-438, 2011.

SKM: Groundwater Modelling Report - Lower Namoi, Draft report by Sinclair Knight Mertz and CSIRO for Murray Darling Basin Authority, 2010.

Smithson, A.: Lower Namoi Groundwater Source - Groundwater Management Area 001 Groundwater Status Report 2008, NSW Department of Water and Energy, Sydney, 2009.

Stauffacher, M., Walker, G., and Evans, R.: Salt and water movement in the Liverpool Plains What's going on?, NDSP Occasional Paper 14/97, 1997.

Thorburn, P. J., Cowie, B. A., and Lawrence, P. A.: Effect of land development on groundwater recharge determined from nonsteady chloride profiles, J. Hydrol., 124, 43-58, 1991.

Timms, W. A.: The Liverpool Plains Water Quality Project: 1996/97 Report on Groundwater Quality, Department of Land and Water Conservation, Centre for Natural Resources, CNR 97.108, 1997.

Timms, W. A. and Acworth, I.: Propagation of porewater pressure change through thick clay sequences: an example from the Yarramanbah site, Liverpool Plains, New South Wales, Hydrogeol. J., 13, 858-870, 2005.

Timms, W. A., Acworth, R. I., and Young, R.: Natural leakage pathways through cracking smectite 5 clay: a hydrogeological synthesis of data from the Hudson Agricultural Trial site on the Liverpool Plains, UNSW Water Research Laboratory, Research Report No. 209, 2002.
Timms, W. A., Cunningham, I. L., Schwarz, M., and Wasko, C.: Hydrogeological investigation of the fate of salt mobilised under dryland cropping on the Cryon Plain, North Western NSWFinal Report, UNSW Water Research Laboratory Technical Report 2008/10, Report to Department of Primary Industries, New South Wales, 2008.

Timms, W. A., Badenhop, A., Rayner, D., and Mehrabi, S.: Namoi groundwater monitoring and evaluation, Report No. 2 Part A Results of 2009 groundwater monitoring and recommendations for future best practice monitoring framework, Part B: Groundwater user survey, UNSW Water Research Laboratory Technical Report 2009/25, 2010.

Tolmie, P. E., Silburn, D. M., and Briggs, A. J. W.: Estimating Deep Drainage in the Queensland Murray-Darling Basin Using Soil Chloride, Queensland Department of Natural Resources and Mines Report QNRM03020, Toowoomba, 2004.

Tolmie, P. E., Silburn, D. M., and Biggs, A. J. W.: Deep drainage and soil salt loads in the Queensland Murray-Darling Basin using soil chloride: comparison of land uses, Soil Res., 49, 408-423, 2011.

Vervoort, R. W., Silburn, M., and Kirby, M.: Near surface water balance in the Northern Murray-Darling Basin, Water Sci. Technol., 48, 207-214, 2003.

Walker, G. R.: Using Soil Water Tracers to Estimate Recharge Part 7 of Basics of Recharge and Discharge, CSIRO Publishing, Collingwood, Victoria, 1998.

Walker, G. R., Jolly, I. D., and Cook, P. G.: A new chloride leaching approach to the estimation of diffuse recharge following a change in land use, J. Hydrol., 128, 49-67, 1991.

Young, R. R.: Mobilization of 100 tonnes of salt/ha under cropping in north western NSW - a threat to agriculture and natural ecosystems?, National Action Plan for Salinity, Final Report, 2009.

Young, R. R. and McLeod, M. K.: Estimation of historic deep drainage under grassed woodland, lucerne pastures and cropped paddocks in the upper Liverpool Plains catchment using the SODICS mode, in: Conference Proceedings 2001 from the 7 th National PUR\$L Conference, 115-119, Launceston, Tasmania, 2001.

Young, R. W., Young, A. R. M., Price, D. M., and Wray, R. A. L.: Geomorphology of the Namoi alluvial plain, northwestern New South Wales, Aust. J. Earth Sci., 49, 509-523, 2002. 